\title{
The Creation of the English Hippocrates
}

\author{
PETER ANSTEY*
}

\begin{abstract}
This article examines the process by which the London physician Thomas Sydenham (1624-89) rose to fame as the English Hippocrates in the late seventeenth century. It provides a survey of the evidence for the establishment of Sydenham's reputation from his own writings, his professional relations, and the writings of his supporters and detractors. These sources reveal that in the first decades of his career Sydenham had few supporters and faced much opposition. However, by the end of the seventeenth century, Sydenham was the object of extraordinary outbursts of adulation and had become renowned for his decrying of hypotheses and speculative theory, his promotion of natural histories of disease, and the purported similarities between his medical method and that of Hippocrates. It is argued that Sydenham's positive reputation owed little to his achievements in medicine: it was almost entirely the result of his promotion by the philosopher John Locke and a small group of sympathetic physicians. It was they who created the English Hippocrates.
\end{abstract}

Keywords: Giorgio Baglivi; Herman Boerhaave; Andrew Brown; College of Physicians; Charles Goodall; John Locke; Thomas Sydenham

On surveying the busts of the English worthies in the Wren Library at Trinity College Cambridge, one cannot help but be struck by the imposing head of Dr Thomas Sydenham (1624-89). Here is the image of a man who is reputed to be the greatest physician of his age, the English Hippocrates, flanked by Inigo Jones and John Milton. Clearly by the mid-eighteenth-century, when this image of Sydenham was installed, ${ }^{1}$ his reputation was fully established. But what were the grounds upon which that reputation was founded?

In this article, I am concerned with the early stages of the creation of Thomas Sydenham's reputation as the archetypal Hippocratic physician. I am not concerned with the propagation and embellishment of that reputation down the centuries, that is, the creation of the two Sydenham societies, ${ }^{2}$ or the process by which Sydenham was

(C) Peter Anstey, 2011.

*Professor Peter Anstey, Department of Philosophy, University of Otago, PO Box 56 Dunedin, 9054, New Zealand. Email: peter.anstey@otago.ac.nz
${ }^{1}$ See Malcolm Baker, 'The Portrait Sculpture', in David McKitterick (ed.), The Making of the Wren Library (Cambridge: Cambridge University Press, 1995), 110-37: 116.

${ }^{2}$ See G.G. Meynell, The Two Sydenham Societies: A History and Bibliography of the Medical Classics 


\section{Peter Anstey}

transformed from being an opponent of what the College of Physicians stood for, to being one of its heroes. Nor am I concerned with claims about Sydenham's influence beyond the field of medicine, such as the way Sydenham has been written into the biography of the philosopher John Locke as one of the seminal influences in the formation of his theory of knowledge. ${ }^{3}$ The focus here is on the process by which a small group of Sydenham's supporters helped to lay the foundation for the creation of the image of Thomas Sydenham as the English Hippocrates.

How then is a reputation created? One way is through the achievements of its bearer. Another way, often complementing the first, is through the promotion of a figure by his or her admirers, neophytes and descendants. I will argue that, in his day, Sydenham had relatively few achievements in any branch of medicine and that the creation of his posthumous reputation is largely owing to a small number of influential supporters, including John Locke. By the late seventeenth century, the reputation that Locke and others had created had at least three salient features: Sydenham the decrier of speculation; Sydenham the natural historian of disease; and Sydenham the Hippocratic physician. It was these facets of his posthumous reputation that made Sydenham the object of profuse adulation in the decades after his death.

\section{Sydenham's Reputation}

First, it is important to come to terms with the extent and resilience of Sydenham hagiography since the eighteenth century. A catena of quotations from the twentieth and twenty-first centuries should set the scene. I will give the author, date and quote in that order:

1. George Newman, 1924

[Sydenham] laid for all time the foundation of the practice of clinical medicine ${ }^{4}$

2. Maurice Cranston, 1957

the greatest English physician ${ }^{5}$

3. Kenneth Dewhurst, 1966

the greatest physician this country has ever produced ${ }^{6}$

4. James Axtell, 1968

the leading doctor of his day ${ }^{7}$

Published by the Sydenham Society and the New Sydenham Society (1844-1911), (Acrise: Winterdown Books, 1985).

${ }^{3}$ See, for example, Roger Woolhouse, Locke: A Biography (Cambridge: Cambridge University Press, 2007), 80-1.

${ }^{4}$ George Newman, Thomas Sydenham: Reformer of English Medicine (New York: Books for Libraries Press, 1924), 32.

${ }^{5}$ Maurice Cranston, John Locke: A Biography (London: Longman, 1957), 91. Cranston goes on to make the extraordinary claim that Sydenham 'was as distinguished in the fields of medical research and therapy as was Robert Boyle in the fields of chemistry and general science', ibid. See also Joseph M. Levine, Dr Woodward's Shield (Berkeley, CA: University of California Press, 1977), 10.

${ }^{6}$ Kenneth Dewhurst (ed.), Dr Thomas Sydenham (1624-1689): His life and Original Writings (London: Wellcome Historical Medical Library, 1966), vii.

${ }^{7}$ James L. Axtell (ed.), The Educational Writings of John Locke (Cambridge: Cambridge University Press, 1968), 70. 
5. G.A.J. Rogers, 2007

probably the greatest physician of the age. ${ }^{8}$

These are not trivial claims, nor are they uncommon. It should also be pointed out, however, that the hagiographic tradition which they represent has not been without its objectors. Hansruedi Isler's 1968 study of Thomas Willis and L.J. Rather's analysis of mid-seventeenth-century pathology of 1974, provided ample evidence to challenge the hegemony of the Sydenham hagiography. ${ }^{9}$ But neither study seems to have had much impact on Sydenham scholarship, or for that matter, on Locke scholarship.

We return then to the question as to how a reputation is created. In the case of Sydenham, does it rest on his achievements in medicine, his promotion by friends and admirers, or perhaps both? In order to answer these questions we need first to turn to Sydenham's achievements before the publication of his Observationes medicae in 1676.

\section{Sydenham before the Publication of Observationes medicae (1676)}

Sydenham moved to London from Oxford around 1655 and probably began practising medicine in the late $1650 \mathrm{~s}$. He received his licence to practise medicine in London from the College of Physicians on 25 June $1663 .{ }^{10}$ By that time he was known to Robert Hooke and Robert Boyle. It is often claimed that Sydenham was a close friend of Boyle, but the little evidence we have suggests to the contrary, that in spite of being a close neighbour in Pall Mall, he was very much on the periphery of Boyle's network of natural philosophers and physicians in the 1660s. ${ }^{11}$ Sydenham is never mentioned by name in Boyle's own extant correspondence or in any of his works. ${ }^{12}$ In fact, it is difficult to determine much about Sydenham's professional life in London before he befriended Locke in mid-1667.

The one event of significance before the onset of that friendship was the publication of his Methodus curandi febres in $1666 .{ }^{13}$ This is an unusual work on three counts. First, it

\footnotetext{
${ }^{8}$ G.A.J. Rogers, 'The Intellectual Setting and Aims of the Essay', in Lex Newman (ed.), The Cambridge Companion to Locke's 'Essay Concerning Human Understanding' (Cambridge: Cambridge University Press, 2007), 7-32: 9.

${ }^{9}$ Hansruedi Isler, Thomas Willis (1621-1675) (New York: Hafner Publishing, 1968); and L.J. Rather, 'Pathology at Mid-Century: A Reassessment of Thomas Willis and Thomas Sydenham', in Allen Debus (ed.), Medicine in Seventeenth-Century England (Berkeley, CA: University of California Press, 1974), 71-112.

${ }^{10}$ See G.G. Meynell, Materials for a Biography of Dr Thomas Sydenham (Folkestone: Winterdown Books, 1988), 17.

${ }^{11}$ The evidence is assessed in John Burrows and Peter Anstey, 'John Locke, Thomas Sydenham and the "Smallpox Manuscripts", English Manuscript Studies, forthcoming. The first explicit mention of Sydenham in Boyle's correspondence is in a letter from Hooke to Boyle of 5 June 1663, in Michael
}

Hunter, Antonio Clericuzio and Lawrence M. Principe (eds), Correspondence of Robert Boyle, 6 vols (London: Pickering and Chatto, 2001), Vol. 2, 84. However, it is almost certain that Boyle had Richard Lower investigate the Oxford University registers of degrees to substantiate Sydenham's claim to an MA. This occurred before he received his licence to practise. No evidence of the degree has ever been found in the University records. See Lower to Boyle, 27 April 1663, in Hunter, Clericuzio and Principe (eds), idem, Vol. 2, 76, and Meynell, op. cit. (note 10), 18.

${ }^{12}$ Boyle does allude to Sydenham as 'the person you mention' in a letter to Henry Oldenburg of 29 December 1667, in Hunter, Clericuzio and Principe (eds), ibid., Vol. 3, 388. For the context of this comment, see the letter referred to in note 18 below.

${ }^{13}$ Thomas Sydenham, Methodus curandi febres (London, 1666), repr. G.G. Meynell (ed.), (Folkestone: Winterdown Books, 1987). 


\section{Peter Anstey}

appeared immediately after the plague of 1665 and yet does not contain a discussion of that disease. Second, it lacks the kind of erudition found in the fevers literature of the period. Third, it shows no interest in, and little awareness of, the heated debates about the status of iatrochemistry, anatomy, phlebotomy and Galenism that were raging in London and in which Locke, Boyle and many of the virtuosi were embroiled in the mid-1660s. In fact, while the Methodus has been praised for its innovative emphasis on observation and decrying of speculative theory, ${ }^{14}$ in comparison with the plethora of contemporary medical publications, its discussion of methodological issues, and especially the role of observation, is surprisingly muted. What it does contain is a highly speculative theory of fevers, which is almost certainly partially derived from the view of Thomas Willis. ${ }^{15}$

The 1660s and early 1670s were not happy years for Sydenham's professional life. In 1668 he wrote to Boyle that 'I. . c cannot brag of my correspondency with some other of my faculty, who... impeach me of great insufficiency'. ${ }^{16}$ We have some insight into the causes of this from scattered sources. A notebook entry by John Ward from c.1666 records Sydenham's criticism of Thomas Willis' competence as a physician, around the time Willis moved to London to establish a medical practice, leaving behind the most prosperous medical practice in Oxford. ${ }^{17}$ A year later Henry Oldenburg was to complain to Boyle of Sydenham's treatment of him while he was in the Tower: 'with so mean and un-moral a Spirit I can not well associate'. ${ }^{18}$ Later Sydenham sympathisers were aware of the opposition he aroused. The physician Andrew Brown, writing after Sydenham's death, recalled that Sydenham had 'gained the sad and unjust recompence of calumny and ignominy; and that from the emulation of some of his collegiate Brethren, \& others, whose indignation at length did culminat to that hight, that they endeavored to banish him, as guilty of Medicinal heresie, out of that illustrious Society'. ${ }^{19}$ These brief but pointed references may give us some insight into why Sydenham was never to become a Fellow of the Royal Society or a Fellow of the College of Physicians.

He also seems to have had trouble securing enough wealthy patients. He spoke to John Mapletoft in 1677 of 'those poor people whom my lott engages me to attend', ${ }^{20}$ and a lack of well-off patients may have been part of the motivation for choosing to dedicate his projected, though abandoned, work on smallpox to Anthony Ashley Cooper - soon to become the Earl of Shaftesbury - in 1670. Certainly that work reveals that he had faced opposition from within medical ranks. He speaks of 'reproaches false reports secret

\footnotetext{
${ }^{14}$ See, for example, Jonathan Walmsley, 'Sydenham and the Development of Locke's Natural Philosophy', British Journal for the History of Philosophy, 16 (2008), 65-83: 67-8.

${ }^{15}$ See Rather, op . cit. (note 9), 83-4 and Isler, op. cit. (note 9), 84-5.

${ }^{16}$ Sydenham to Boyle, 2 April 1668, in Hunter, Clericuzio and Principe (eds), op. cit. (note 11), Vol. $4,56$.

17 'Sydenham and some others in London say of Dr. Willis that hee is an ingenious man but not a good physitian, and that hee does not understand the way of practice', quoted from Meynell, op. cit. (note $10), 68$.
}

\footnotetext{
${ }^{18}$ Henry Oldenburg to Boyle, 24 December 1667, in Hunter, Clericuzio and Principe (eds), op . cit. (note 11), Vol. 3, 386.

${ }^{19}$ Andrew Brown, A Vindicatory Schedule Concerning the Cure of Fevers (Edinburgh, 1691), 83. Locke owned a copy that is listed in John Harrison and Peter Laslett (eds), The Library of John Locke, 2nd edn (Oxford: Clarendon Press, 1971), No. 496.

${ }^{20}$ Dewhurst, op. cit. (note 6), 170. Sydenham was probably working amongst the poor in the late 1660s. See G.G. Meynell (ed.), Thomas Sydenham's

'Observationes medicae' and his 'Medical Observations' (Folkestone: Winterdown Books, 1991), 26-7.
} 


\section{The Creation of the English Hippocrates}

\& open defamation'. ${ }^{21}$ Sydenham may be alluding here to critical reactions to his cooling regime for smallpox and to the sort of attack that was soon to appear in Henry Stubbe's published accusation that Sydenham had plagiarised medical receipts from Tobias Whitaker's earlier book on smallpox. ${ }^{22}$

The fact that Sydenham would address a dedicatory epistle to Lord Ashley for the work on smallpox has been taken to indicate that Sydenham was engaged in the Ashley household as a physician. ${ }^{23}$ Indeed, he claims as much in his comment that 'that I have practised noething in your family but what I durst owne \& publish to the world' ${ }^{24}$ However, there is very little evidence, beyond one bill for a visit to a servant, ${ }^{25}$ that Sydenham was regularly engaged in the Ashley household before 1673. The only independent evidence of regular visits is a series of bills for medical receipts in late 1673 for a period of three months. ${ }^{26}$

In fact, even the episode that gave rise to Sydenham's complaint about being consigned to work among the poor is revealing of his poor relations with the medical fraternity. For Mapletoft, writing to Locke in Paris, supplied Sydenham's advice for Lady Northumberland's trigeminal neuralgia, but advised that Sydenham's name be suppressed. Whatever the reason for this act of 'name suppression', it is clear that Sydenham's reputation in some quarters was not good. ${ }^{27}$

It is little wonder then that one characteristic of most of Sydenham's extant writings from this period is his concern with his own reputation as a physician. In his letter to Boyle of 2 April 1668 he claims to 'have the happiness of curing my patients, at least of having it said concerning me, that few miscarry under me' ${ }^{28}$ In the short preface to the projected work on smallpox he speaks of his own reputation on four separate occasions. He speaks of 'my credit and profit'; 'my owne Interest \& reputation'; 'my esteeme $\&$ reputation'; 'endangring not only of my reputation \& lively hood but even my life its self' ${ }^{29}$ Similar concerns are found in his Medical Observations, which was to form the basis of his later Observationes medicae. ${ }^{30}$

\footnotetext{
${ }^{21}$ Dewhurst, ibid., 101 (corrected).

${ }^{22}$ Henry Stubbe, The Lord Bacons Relation of the Sweating-Sickness (London, 1671), 175-7; see also Tobias Whitaker, An Elenchus of Opinions Concerning the Cure of the Small Pox (London, 1661).

${ }^{23}$ See Donald G. Bates, 'Thomas Sydenham: The Development of his Thought, 1666-1676' (unpublished $\mathrm{PhD}$ thesis: Johns Hopkins University, 1975), 355. See also Woolhouse, op. cit. (note 3), 80. It should be pointed out that Ashley is nowhere explicitly named as the dedicatee in the Dedicatory Epistle, but that the weight of internal and external evidence renders it virtually certain that the work was composed for Ashley. See Burrows and Anstey, op. cit. (note 11).

${ }^{24}$ Dewhurst, op. cit. (note 6), 102 (corrected).

${ }^{25}$ Sydenham was paid one pound one shilling for attending to a Mrs Jane. See National Archives, Kew (hereafter NA), PRO 30/24/40/44, fol. 2v.

${ }^{26}$ Bills for medicines 'by Dr Sidnham's order' are at NA PRO 30/24/4/216/33, fols 337-40
}

(August-October 1673; paid 6 June 1674) and a receipt for $£ 10$ for visiting Sir William Hanham, dated 4 August 1673 is at NA PRO 30/24/4/216/28, fols 327-8.

${ }^{27}$ Mapletoft writes 'I thought it not best to mention these our Friend's directions for reasons you may know, yet I beleivd you would not be displeased to have his opinion too in a case of this difficulty and concernment, which you may make use of as you find cause', E.S. de Beer (ed.), Correspondence of John Locke (Corr.), 8 vols (Oxford: Clarendon Press, 1976-89), Vol. 1, 537.

${ }^{28}$ Sydenham to Boyle, 2 April 1668, in Hunter, Clericuzio and Principe (eds), op. cit. (note 11), Vol. 4, 56.

29 'Preface', in Dewhurst, op. cit. (note 6), 103, 104.

${ }^{30}$ Sydenham, cited in Meynell (ed.), op. cit. (note 20), 11 and 97-8. See also Sydenham, op. cit. (note 13), 53. Indeed, Sydenham's concern with his reputation, often his posthumous reputation, is a hallmark of most of his writings. For a sampling of 


\section{Peter Anstey}

\section{Sydenham's Early Relations with Locke}

However, it was not all doom and gloom for Thomas Sydenham in the early decades of the Restoration, not least because it was during those years that he forged the most important friendship of his life: he befriended John Locke. Locke appears first to have encountered Sydenham in the spring of 1667 after his move from Oxford to the house of Anthony Ashley Cooper. Their relations were most intense from 1667 until early 1673 when Locke mentioned to John Mapletoft that other concerns meant that he was unable to make visits to patients with Sydenham. ${ }^{31}$

If Sydenham's relations with the medical fraternity and with the virtuosi were hardly productive, his relations with Locke could not have been more different. In late 1667, Locke composed an adulatory poem about the second edition of Methodus which appeared in 1668. Furthermore, G.G. Meynell has convincingly argued that Locke had an important role in the major addition to the second edition, namely, a new chapter on the plague. This chapter bears the marks of Locke's extensive medical reading in the mid-1660s and betrays a level of erudition that is unparalleled in Sydenham's writings. ${ }^{32}$ Before long, Locke was accompanying his new friend on his visits to patients suffering from smallpox. ${ }^{33}$

In the winter of 1668 , Locke was intimately involved in a serious operation on a large hydatid cyst above Lord Ashley's liver. During his convalescence, Ashley sought advice on the wisdom of retaining the short silver pipe which protruded from the wound in his side. Among the advice he received is a set of replies from Sydenham. ${ }^{34}$ There is no evidence of prior involvement in Ashley's case by Sydenham, and it may be that the advice was solicited by Locke, who also tendered his own answers to Ashley's queries. ${ }^{35} \mathrm{Be}$ that as it may, this episode at least provided for Sydenham a link with the Ashley household, a link that Locke was soon to foster. For, as mentioned above, in 1670, Sydenham began to compose a work on smallpox dedicated to Ashley. Recent analysis of the surviving fragments of this work using computational stylistics has revealed that the dedicatory epistle and parts of the preface were composed by Locke. ${ }^{36}$ Whatever the motivation for this work, and in spite of the fact that it was abandoned, it provides further evidence of Locke's promotion of Sydenham's cause and of Locke and Sydenham's friendship. From this period too we begin to find copies in Locke's hand of medical essays by Sydenham, many of which later found their way into the latter's Observationes medicae of 1676. It is clear from some of the earliest of these essays that occasionally Locke even acted as Sydenham's amanuensis.

references to his posthumous reputation and legacy see: Sydenham to Dr William Gould, 10 December 1687 in Dewhurst, ibid., 174; Epistle to Dr Brady, in Robert Gordon Latham (ed.), The Works of Thomas Sydenham, 2 vols (London, The Sydenham Society, 1848), Vol. 2, 6; Treatise on gout and dropsy, ibid., 122; Schedula monitoria, ibid., 189.

${ }^{31}$ Locke to John Mapletoft, 14 February 1673, in de Beer (ed.), op. cit. (note 27), Vol. 1, 378.

${ }^{32}$ G.G. Meynell, 'Sydenham, Locke and Sydenham's De peste sive febre pestilentiali', Medical History, 36 (1993), 330-2.

\footnotetext{
${ }^{33}$ Sydenham to Boyle, 2 April 1668, in Hunter, Clericuzio and Principe (eds), op. cit. (note 11), Vol. 4, 55 .

${ }^{34}$ Sydenham's advice is transcribed in Dewhurst, op. cit. (note 6), 164-6.

${ }^{35}$ Transcribed in Sir William Osler, 'John Locke as a Physician’, Lancet, 156 (20 October 1900), 1119-20.

${ }^{36}$ See Burrows and Anstey, op. cit. (note 11).
} 


\section{The Creation of the English Hippocrates}

In Locke, Sydenham had found a real friend, someone who actively championed his cause and someone whose learning and connections were of great benefit to him. This is all the more interesting because of the quite striking differences between the medical orientation of the two men. From the late 1650s, Locke had been equipping himself as a physician. In many respects he was an autodidact, embarking on an extensive reading programme in all aspects of medicine. Yet he had some very expert guidance. It is now clear that he learned chymistry from Robert Boyle, and that from the early 1660s he imbibed a blend of Boyle's form of mercurialist transmutational chymistry and Helmontianism, the latter of which was very popular amongst the chymical physicians of the 1660s. Correspondence that has only recently surfaced, together with Locke's own chymical notebooks, reveal that Locke was very clearly shaping as a chymical physician and closely aligned with their outlook, if not their political and professional aspirations. ${ }^{37}$

It has long been known, for example, that Locke was engaged with the very exciting series of anatomical experiments and physiological theorising that flourished in Oxford in the 1660 s. ${ }^{38}$ Locke saw with his own eyes some of the ground-breaking experiments on respiration that were predicated upon William Harvey's own anatomical discoveries. Yet in spite of this first hand exposure to the power of the new anatomical researches in Oxford, just weeks after Ashley's convalescence in late 1668, Locke penned an essay arguing against the efficacy of gross anatomy in therapeutics. Some previous commentators have taken Locke's Anatomia to be a statement of his opposition to experiment and to traditional medicine. ${ }^{39}$ However, the chymical physicians and even Boyle himself, held strong views on the utility of anatomy in physic. ${ }^{40}$ In fact, the strong verbal and thematic parallels (hitherto unnoticed) between Locke's Anatomia and a fragment by Boyle on anatomy suggest that their views may have formed in unison. ${ }^{41} \mathrm{Be}$ that as it may, Locke's essay is exactly what one would expect from one aligned with the chymical physicians. It is not a repudiation of the investigative physiology he experienced just a few years before, ${ }^{42}$ nor is it a wholesale rejection of anatomy. It is a further indication

\footnotetext{
${ }^{37}$ See John Read to Locke, April 1666, in Hunter, Clericuzio and Principe (eds), op. cit. (note 11), Vol. 3, 11-14. For a full discussion of Locke's chymistry and his connections with the chymical physicians, see Peter Anstey, 'John Locke and Helmontian Medicine', in Charles Wolfe and Ofer Gal (eds), The Body as Object and Instrument of Knowledge:

Embodied Empiricism in Early Modern Science (Dordrecht: Springer, 2010), 93-117.

${ }^{38}$ See Robert G. Frank Jr, Harvey and the Oxford Physiologists (Berkeley, CA: University of California Press, 1980).

${ }^{39}$ See, for example, David E. Wolfe, 'Sydenham and Locke on the Limits of Anatomy', Bulletin of the History of Medicine, 35 (1961), 193-220, and François Duchesneau, L'empirism de Locke (The Hague: M. Nijhoff, 1973).

${ }^{40}$ For the attack on anatomy in English medicine, see Andrew Wear, Knowledge and Practice in English Medicine, 1550-1680 (Cambridge: Cambridge University Press, 2000), 442-8. For Boyle on medical method, see Michael Hunter, 'Boyle
}

Versus the Galenists: A Suppressed Critique of Seventeenth-Century Medical Practice and its Significance', in Michael Hunter, Robert Boyle 1627-1691: Scrupulosity and Science (Woodbridge: Boydell, 2000), 157-201.

${ }^{41}$ Locke claims 'All that anatomie can doe is only to shew us the grosse \& sensible parts of the body, or the vapid \& dead juices' (Dewhurst, op. cit. (note 6), 85 ), while Boyle says 'For all anatomy can do, is to manifest or display the structure of the consistent parts, such as the bones, cartilages, nerves, arteries, veins etc. and expose to our senses the visible liquors of the body, such as blood, gall, the concreted juices, urine, etc'. Unhappily, the Boylean fragment only survives as a paragraph in the posthumous Christian Virtuoso, II, in Michael Hunter and E.B. Davis (eds), Works of Robert Boyle, 14 vols (London: Pickering and Chatto, 1999-2000), Vol. 12, 473, and we know nothing of its date of composition.

${ }^{42}$ Pace Jonathan Walmsley, 'John Locke on Respiration', Medical History, 51 (2007), 453-76: 474. 


\section{Peter Anstey}

of the sort of physician that Locke had become and this is decidedly different to the orientation of Thomas Sydenham.

Sydenham had dealings with chymically inclined physicians such as Daniel Coxe, but he neither turned his hand to chymistry nor embraced a determinate matter theory. ${ }^{43} \mathrm{He}$ may have adopted his emphasis on observation over theory and book learning, and the stance against anatomy from the medical reformers, ${ }^{44}$ but he never aligned himself with their party. Moreover, at least since the 1650s, there had been a strong emphasis amongst British physicians on observation and experiment.

More importantly, however, it is clear that in the late 1660s, Sydenham came to learn of the vogue amongst natural philosophers and physicians for the construction of Baconian-style natural histories. This was after he met Locke, and the most likely source of influence on this aspect of Sydenham's medical method was Locke himself. There is no mention of natural histories in either edition of the Methodus of 1666 and 1668, even though by this time the method of natural history had been widely promoted and practised by natural philosophers and physicians alike. Locke himself had been involved in some of Boyle's natural historical projects at least since early 1666. It is hardly surprising then that Locke's essays on medical methodology entitled Anatomia and De arte medica subscribed to the method of natural history, and there is strong evidence that Sydenham was familiar with the contents of them. Therefore, given the fact that the term 'naturall hystory' first appears in Sydenham's writings in July 1669 (in his new manuscript notes on smallpox), ${ }^{45}$ it seems likely that it was Locke who stressed to Sydenham the importance of the construction of natural histories of diseases. ${ }^{46}$

After four or five years of close interaction, Locke and Sydenham appear never to have engaged with the same degree of frequency again. Locke was in France for much of the latter half of the $1670 \mathrm{~s} .{ }^{47}$ On his return he seems to have re-established contact with Sydenham and to have spent considerable time copying some of his essays, some of which had earlier appeared in print in the Observationes medicae of 1676. Locke then went into exile in The Netherlands from 1683 until late in the decade, and by the time of his return, Sydenham's health was failing: he died on 29 December 1689.

\section{Sydenham's British Supporters from 1676}

The year 1676 proved to be something of a turning point in Sydenham's fortunes. To be sure, opposition continued, but over the next decade a small number of disparate supporters emerged within the medical fraternities of England and Scotland, one of whom Charles Goodall - was to hold strategic positions within the College of Physicians.

\footnotetext{
${ }^{43}$ See Daniel Coxe to Boyle, 14 October 1666, in Hunter, Clericuzio and Principe (eds), op. cit. (note 11), Vol. 3, 249. For Sydenham's later view of chymistry, see Works of Thomas Sydenham, op. cit. (note 30), Vol. 2, 172.

${ }^{44}$ The evidence for Sydenham's early views on anatomy rests on an interpolated comment preceding the opening of Locke's Anatomia. See Dewhurst, op cit. (note 6), 85. For Sydenham's later view see 'On Dropsy', Works of Thomas Sydenham, op. cit. (note
}

30), Vol. 2, 171-2; originally published in De podagra et hydrope (London, 1683).

${ }^{45}$ Sydenham, cited in Meynell (ed.), op. cit. (note 20), 74

${ }^{46}$ For further discussion see Peter Anstey and John Burrows, 'John Locke, Thomas Sydenham, and the Authorship of Two Medical Essays', Electronic British Library Journal, 3 (2009), 1-42: 19-22.

${ }^{47} \mathrm{He}$ arrived in France on 15 November 1675 and returned on 9 May 1679. 


\section{The Creation of the English Hippocrates}

It may be that relations between Oldenburg and Sydenham had begun to thaw because in May 1676 he had Sydenham convey a package to Isaac Newton in Cambridge, and it was in Cambridge that Sydenham received a doctorate in medicine, on that very trip. ${ }^{48}$ However, the first strong evidence we have for a change in Sydenham's fortunes is in a publication by Charles Goodall. Goodall, whose Leiden MD was incorporated at Cambridge in 1670, defended the College of Physicians in their skirmish with Adrian Huyberts in a short work entitled The Colledge of Physicians Vindicated, which was written in 1675 and published the following year. In it Goodall lists Sydenham as one of a group of eminent licentiates of the College. He goes on to refer approvingly to the section on plague in the second edition of the Methodus. Interestingly, he refers to the very material for which Meynell has shown that Locke was responsible, quoting a Latin extract which immediately follows criticism of Diemerbroek, to whom Goodall then refers. Goodall then proceeds to discuss Sydenham's method of treatment for smallpox and to allude to his method of treatment for ileus. ${ }^{49}$ Goodall's publication should not, however, be taken to be evidence of a thawing of relations between Sydenham and the Fellows of the College, for at the time Goodall himself was not a Fellow. In fact, the work is in part a defence of the College that was strategically aimed at promoting Goodall's own aspirations to become one. ${ }^{50} \mathrm{He}$ was eventually rewarded with a Fellowship in April 1680. ${ }^{51}$

It is not known when Sydenham made the acquaintance of Goodall, but Goodall's approving excerpts of Sydenham's Methodus seem to have formed the foundation of a friendship that was affirmed in print by Sydenham in $1680 .^{52}$ By mid-1680, Locke had also established relations with Goodall: references to Goodall in his journal begin in June of that year. ${ }^{53}$ Sydenham was later to allude to Goodall's support in another passage concerned with his reputation in his Epistolary Dissertation of 1685,

\footnotetext{
${ }^{48}$ See Oldenburg to Newton, 15 May 1676, in H.W. Turnbull (ed.), Correspondence of Isaac Newton: Volume II, 1676-1687 (Cambridge: Cambridge University Press, 1960), 7. It is also likely that Oldenburg also sent a copy of Sydenham's Observationes medicae to Marcello Malpighi in late 1676: Malpighi to Oldenburg, 5 January 1677, in Howard B. Adelmann (ed.), Correspondence of Marcello Malpighi, 5 vols, (Ithaca, NY: Cornell University Press, 1975), Vol. 2, 746.

${ }^{49}$ Charles Goodall, The Colledge [sic] of Physicians Vindicated, and the True State of Physick in this Nation Faithfully Represented (London, 1676), $34,175-7$ and 185 . For an analysis of this controversial work see Harold J. Cook, The Decline of the Old Medical Regime in Stuart London (Ithaca, NY: Cornell University Press, 1986), 199-201.

${ }^{50}$ One can almost hear Goodall addressing the Fellows of the College when he says, in relation to Candidates, who took their degrees in foreign Universities, and are therefore obliged to incorporate in one of our own, before they be admitted into the Colledge; you may observe the Colledge, like
}

trueborn English-men, so much concerning themselves for the welfare and honour of their own Countrey, and reputation of the two famous Universities of this Land; that their being foreigners by birth, or non-incorporating into one of our own Academies, (though degrees have been taken in others) is a sufficient bar to their being admitted as Candidates', Goodall, ibid., 34-5.

${ }^{51}$ See Harold J. Cook, 'Goodall, Charles (c.1642-1712)', Oxford Dictionary of National Biography (Oxford: Oxford University Press, 2004), online: <http://www.oxforddnb.com/view/article/ 10949>, accessed 11 April 2011.

52 ' $[\mathrm{M}] \mathrm{y}$ friend Dr Charles Goodall, the mention of whose name reminds me of his candour, probity, friendship, and medical skill, to a patient...', Epistles to Dr Brady and Dr Paman, Works of Thomas Sydenham, op. cit. (note 30) Vol. 2, 8.

${ }^{53}$ Kenneth Dewhurst, John Locke (1632-1704), Physician and Philosopher: A Medical Biography (London: Wellcome Historical Medical Library, 1963), 190. 


\section{Peter Anstey}

Dr Goodall was the friend who, when many men ventured to assert that I had done but little in the investigation and cultivation of medicine, threw himself in the way of my maligners, and defended me with the zeal and affection of a son towards a father. ${ }^{54}$

Whether or not Sydenham is alluding here to the affirmation of Sydenham's Methodus in Goodall's Vindication, it is clear that their friendship was founded upon Sydenham's perception of Goodall's support for his reputation as a physician.

But by the time of these comments, Goodall's support had turned into almost unbridled admiration. In a politically astute and carefully crafted history of the College of Physicians, Goodall lists Sydenham in a list of eminent English physicians. Here is how his eulogy begins,

Dr Sydenham (whom I can never name, without owning my great obligations for the many happy advantages which I have received from his most ingenious learned, and free conversation) hath highly obliged the World, and all ingenuous Men of our Profession, with many incomparable Treatises, lately published; which are drawn (as it were by another Hippocrates) from his most exact and nice observation of Diseases, and their symptomes; to which are added most judicious, Natural Hypotheses, and Curative Indications, deduced from them; He hath given such an exact History of all acute Diseases from the beginning of 1661, to 1680. that there is scarcely a Sentence to be found therein, which is not of moment. ${ }^{55}$

This is extraordinary on three counts. First, Sydenham is positioned here in a 'gallery of greats' of the College, of which he was not even a Fellow and whose earlier opposition to him (if Andrew Brown is to be believed) 'did culminat to that hight, that they endeavored to banish him, as guilty of Medicinal heresie, out of that illustrious Society'. The irony of the fact that Sydenham was now being used to enhance the College's public image is palpable. Second, it contains the first explicit comparison between Sydenham and Hippocrates, a comparison that would eventually lead to the epithet by which Sydenham is known today. Third, it contains the first independent acknowledgment in print of Sydenham's natural historical method.

It is not, however, the first acknowledgment of Sydenham's natural histories, for they had been mentioned in a letter to Sydenham by Robert Brady which Sydenham printed to preface his published Epistle to Brady in $1680 .{ }^{56}$ (Incidentally, Brady's letter also refers to imminent 'rebukes of malevolent men and the calumnies of the envious' claiming that '[t]hese will attack your reputation, now as before'.)

The mutual admiration between Sydenham and Goodall continued, for in 1686 Sydenham dedicated his Schedula monitoria to Goodall, in part because Goodall was the 'one whose patronage has protected me against all who have opposed me'. ${ }^{57}$ Surprisingly, in spite of claims about the influence of Sydenham's Observationes medicae in recent scholarship, ${ }^{58}$ it was almost certainly the Schedula monitoria that finally brought Sydenham

\footnotetext{
${ }^{54}$ Epistolary Dissertation, Works of Thomas Sydenham, op. cit. (note 30) Vol. 2, 83.

${ }^{55}$ Charles Goodall, The Royal College of Physicians of London, Founded and Established by Law; as Appears by Letters Patents, Acts of Parliament, Adjudged Cases, \&c. and An Historical Account of the College's Proceedings against
}

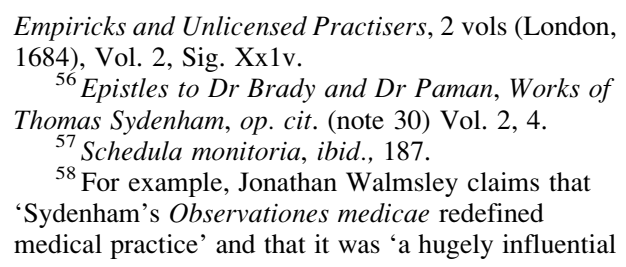
1684), Vol. 2, Sig. Xx1v.

${ }^{56}$ Epistles to Dr Brady and Dr Paman, Works of Thomas Sydenham, op. cit. (note 30) Vol. 2, 4.

${ }^{57}$ Schedula monitoria, ibid., 187.

${ }^{58}$ For example, Jonathan Walmsley claims that 'Sydenham's Observationes medicae redefined medical practice' and that it was 'a hugely influential 


\section{The Creation of the English Hippocrates}

in from the cold. In the first place, Sydenham, in the dedicatory epistle to Goodall, claims that he now regards his previous treatises on 'the history and cure of diseases' as 'lame and imperfect' and that he is 'more likely to take shame than credit for them'. 59 This work on new fevers, then, is Sydenham's final and most 'mature' contribution to the history and treatment of fevers and, by his own admission, supersedes both the Methodus and the Observationes medicae. It appears that this is how the book was received.

For example, in his Vindicatory Schedule, Andrew Brown testifies to the fact that it was the Schedula monitoria that influenced him to travel from Edinburgh to London to meet Sydenham and thereafter to apply Sydenham's method in his own practice. ${ }^{60}$ Likewise, it was this work that was praised by Walter Harris in his De Morbis infantum (1689). Furthermore, the second edition of 1688 was published under the newly acquired imprimatur of the College of Physicians and contains a panegyric poem for Sydenham by Edward (later Sir) Hannes of Christ Church. ${ }^{61}$ Thus, finally in the last two years of his life, Sydenham was publically aligned with the College.

Brown's Vindicatory Schedule, however, can hardly be regarded as a robust and independent source of support for Sydenham, for it is, in fact, a defence Brown's own unsuccessful deployment of Sydenham's method of curing continual fevers in the ill-fated case of Lord Creichton. In arguing for the efficacy of Sydenham's 'New, but most Effectual Method of Curing Continual Fevers, Invented', Brown defended himself against the charges of the Edinburgh medical fraternity. ${ }^{62}$ Not surprisingly, Brown's work is replete with the kind of adulation that was to become a hallmark of most references to Sydenham by his promoters from the 1690s. He is described as 'Sagacious', 'expert', 'Noble and Famous', 'that incomparible, sagatious, and expert Practitioner', 'incomparable practitioner', 'Magnanimous', 'the great Ornament and Light of this Age' (quoting Harris) and so on. ${ }^{63}$ But more importantly, Brown, desperate to bolster Sydenham's authority and so to justify his own practice, provides the reader with a kind of summary history of the favourable reception of Sydenham's ideas. He first lists the English physicians who supported Sydenham. Goodall comes first, then Brady and Paman (to whom Sydenham addressed his second Epistle), then Dr William Cole (to whom Sydenham addressed his Epistolary Dissertation). ${ }^{64}$ Next, Sir John Micklethwaite is reported to

work which would eventually secure Sydenham's reputation and become a landmark in therapeutics' ('Sydenham', op. cit. (note 14) 80 and 72) and Gianna Pomata claims that Sydenham's Observationes medicae 'marked a decisive transformation of the genre [of Observationes]', Gianna Pomata, 'Sharing Cases: The Observationes in Early Modern Medicine', Early Science and Medicine, 15 (2010), 193-236: 226. Neither author provides any evidence to support their claims.

${ }^{59}$ Works of Thomas Sydenham, op. cit. (note 30) Vol. 2, 188.

${ }^{60}$ Brown, op. cit. (note 19), Sig. \ๆ2.3.

${ }^{61}$ Surprisingly, this poem is omitted from Latham's edition of The Works of Thomas Sydenham, op. cit. (note 30) and is neither mentioned in J.F. Payne's Thomas Sydenham (London: T. Fisher Unwin, 1900) nor Kenneth Dewhurst's Dr Thomas
Sydenham, op. cit. (note 6), nor G.G. Meynell's Materials for a Biography of Dr Thomas Sydenham, op. cit. (note 10). The poem was reprinted in Anon., Musarum anglicanarum analecta, sive Poemata quaedam melioris notae (Oxford, 1692), 90-3.

${ }^{62}$ Brown, op. cit. (note 19), 1. For the context and an analysis of Brown's book, see Andrew

Cunningham, 'Sydenham Versus Newton: The Edinburgh Fever Dispute of the 1690s between Andrew Brown and Archibald Pitcairne', Medical History Supplement, 1 (1981), 71-98. An anonymous referee for this article alerted me to this reference.

${ }^{63}$ Brown, ibid., preface and 30, 80, 84, 92.

${ }^{64}$ In fact, Cole had mentioned Sydenham in passing in his A Physico-Medical Essay Concerning the Late Frequency of Apoplexies (Oxford, 1689), 113. 


\section{Peter Anstey}

have said, when nearing death and therefore with a clearer perception of things, that Sydenham's method would prevail, and finally, Brown lists Richard Morton's Phthisiologia (1689) and Walter Harris' De morbis acutis infantum (1689), both of which praise Sydenham, the latter affirming the method of his Schedula monitoria. ${ }^{65}$

Brown also lists three foreign authors who had referred to Sydenham's works. Of note is the reference to Jacob Spon's Obserations sur les fièvres et les fébrifuges, Lyon, 1681 (English translation, 1682). Spon says of Sydenham,

He printed (about four or five years since) his Observations upon Acute Diseases, wherein there are excellent methods for the cure of many Diseases; and of Fevers also, which he cures so perfectly, that at London he is called the Fever-Doctor; and yet for all this, we do not see that his method is much used. ${ }^{66}$

Interestingly, Brown was probably not the first amongst Sydenham's friends and supporters to note Spon's reference to Sydenham, for Locke's endorsement of a letter from Goodall of 25 July 1687 contains a reference to the French edition of this work, and Locke's library contained both the French and English editions. ${ }^{67}$ Nevertheless, these foreign authors were hardly worth mustering to Brown's cause, for as his adversary James Forrest was to point out, all of their references to Sydenham predate the publication of the Schedula monitoria and, therefore, provide no endorsement of Sydenham's new method for the cure of continual fevers. ${ }^{68}$

Thus, when taken in its polemical context, Brown's book was hardly impressive support for Sydenham. In fact, it is noteworthy that of the eight British physicians who supported Sydenham, only one of them, Goodall, did so in print before the year of Sydenham's death, and his two endorsements of Sydenham appeared in self-promoting and politically oriented works, respectively. None of these published endorsements of Sydenham's method had much clout. What was needed was an independent and authoritative affirmation of Sydenham's contribution. This was provided by John Locke.

\section{Locke's Promotion of Sydenham}

Before proceeding to the decisive phase of Locke's promotion of Sydenham's reputation, let us list Locke's positive contribution to Sydenham's reputation before the end of 1689 .

The starting point is the adulatory poem recommending the second edition of the Methodus of 1668. Locke's sentiments here were not merely a product of the panegyric genre, for we find that he concluded a draft essay on smallpox, which had clearly been dictated to him by Sydenham in 1669, with the phrase 'Written by that Genius of Physick

\footnotetext{
${ }^{65}$ See Richard Morton, Phthisiologia seu exercitationes de phthisi (London, 1689), Sig a1v-a2r and Walter Harris, De morbis acutis infantum (London, 1689), 45-51.

${ }^{66}$ Jacob Spon, Observations on Fevers and Febrifuges (London, 1682), 7-8. Brown also mentions Michael Ettmüler of Leipzig and Johann Dolaeus, physician to the Landgrave of Hesse, as giving favourable mentions of Sydenham; Brown, $o p$ cit. (note 19), 86-7.
}

\footnotetext{
${ }^{67}$ Goodall to Locke, 25 July 1687 , in de Beer (ed.), op. cit. (note 27), Vol. 3, 234; Harrison and Laslett (eds), op. cit. (note 19), No. 2751 and No. 2751a.

${ }^{68}$ James Forrest, A Brief Defence, of the Old and Succesful Method of Curing Continual Fevers in Opposition to Doctor Brown and his Vindicatory Schedule (Edinburgh, 1694), 152.
} 


\section{The Creation of the English Hippocrates}

Dr Sydenham,. ${ }^{69}$ After the re-publication of the Methodus, Locke assisted Sydenham in his quest to enhance his standing in the Ashley household. This may have been with a view to securing more wealthy patients, but whatever the reason, Locke's composition of the dedicatory epistle for the aborted work on smallpox is clearly an attempt to advance his friend's situation. The fact that Sydenham was later to work in the Ashley household, albeit for only a few months, is probably a tangible outcome of Locke's efforts.

The next public connection between the two men appears some six years later in the dedicatory epistle to Sydenham's Observationes medicae, in which Sydenham explicitly states that his medical methodology, spelt out in the preface to the work, is endorsed by Locke. $^{70}$ This may be an implicit acknowledgment of Locke's input into this methodological essay. In fact, G.G. Meynell has argued quite persuasively that the preface does bear the marks of Locke's input, ${ }^{71}$ though this cannot be established using computational stylistics because it only survives in Latin translation.

Locke continued to promote Sydenham throughout his time in France, distributing copies of the Observationes medicae and seeking out the views of others on Sydenham's publications. ${ }^{72}$ He wrote to John Mapletoft in June 1677,

I could not get a booke [Observationes medicae] of his to Montpellier till the weeke after I had left it. I shall be glad to heare that it every day gains ground, though that be not always the fate of usefull truth, especially at first seting out. I shall perhaps be able to give him an account of what some ingenious men thinke of it here. ${ }^{73}$

He also continued to respect and seek Sydenham's medical advice for himself and others and to express concern for Sydenham's own health. ${ }^{74}$

The same pattern continued in the 1680s during Locke's exile in The Netherlands. For example, Locke wrote to Mary Clarke on 9 March 1688,

I am exceedingly glad that the measles is so well over, which is a disease not without danger in the old way of tampering. I know if you had either Dr. Sydenham or Goodall they used neither hot remedies nor hot keeping, which is a rule I advise you to observe, if any of your children should have the same disease in the country. ${ }^{75}$

${ }^{69}$ Bodleian Library MS Locke f. 21, 17. See Sydenham, cited in Meynell (ed.), op. cit. (note 20), 98.

${ }^{70}$ See Thomas Sydenham, Observationes medicae (London, 1676), Sig. A6r = in Latham, op. cit. (note 61), Vol. 1, 6. For the text of the preface see G.G. Meynell, 'John Locke and the Preface to Thomas Sydenham's Observationes medicae', Medical History, 50 (2006), 93-110: 101-10.

${ }^{71}$ Meynell, ibid.

${ }^{72}$ Locke asked Thomas Stringer to send him three copies of Sydenham's Observationes medicae (1676) while he was in Montpellier, two of which he gave to Dr Brouchier and Barbeyrac. See Thomas Stringer to Locke, 5 June 1676, in de Beer (ed.), op. cit. (note 27), Vol. 1, 446-7.
${ }^{73}$ Locke to Mapletoft, 12/22 June 1677, in ibid., Vol. 1, 492.

${ }^{74}$ Locke to Mapletoft, 30 July/9 August 1677, ibid., Vol. 1, 504. See also Mapletoft to Locke, 28 June 1676, idem, Vol. 1, 450; Sydenham to Locke, 4 June 1677, idem, Vol. 1, 488-9; William Charleton to Locke, 22 January 1678, idem, Vol. 1, 546; Sydenham to Locke, 30 August 1679, idem, Vol. 2, 80; and 6 September 1679, idem, Vol. 2, 94.

${ }^{75}$ Locke to Mary Clarke, 28 February/9 March 1688, ibid., Vol. 3, 386. Dewhurst was right to claim that '[i]t was mainly through Locke's constant advocacy that Sydenham's works came to be more highly regarded in Holland than in England', Dewhurst, op. cit. (note 53), 282. 


\section{Peter Anstey}

Locke also acquired two adulatory poems about Sydenham, in Greek, written by Mattheus Sladus, probably in the mid-1680s. ${ }^{76}$

From the early 1690s, however, there is a discernible shift in Locke's comments about Sydenham and it is this, I shall argue, that marks the decisive phase in his promotion of his friend and which had a marked influence upon Sydenham's reputation in the following century. It is this shift that crystallises Locke's view of Sydenham as a medical methodologist. In short, all of Locke's positive comments about Sydenham are concerned, not with his contribution to diagnostics or therapeutics, but rather with his practice of Experimental Philosophy as a physician.

I have argued elsewhere that the salient methodological distinction in early modern natural philosophy is that between Experimental and Speculative Philosophy. ${ }^{77}$ Experimental Philosophy is to be distinguished from Speculative Philosophy in so far as it emphasises observation and experiment and decries the development of speculative theories and hypotheses. This distinction is almost ubiquitous in late seventeenth-century England. Perhaps the best popular expression of it is in John Dunton's The Young-Students-Library of 1692:

Philosophy may be consider'd under these two Heads, Natural and Moral: The first of which, by Reason of the strange Alterations that have been made in it, may be again Subdivided into Speculative and Experimental.

... we must consider, the distinction we have made of Speculative and Experimental, and, as much as possible, Exclude the first, for an indefatigable and laborious Search into Natural Experiments, they being only the Certain, Sure Method to gather a true Body of Philosophy; for the Antient Way of clapping up an entire building of Sciences, upon pure Contemplation, may make indeed an Admirable Fabrick, but the Materials are such as can promise no lasting one. ${ }^{78}$

Now, in the epistle to the reader of Locke's most important philosophical work, An Essay concerning Human Understanding, Locke lists Sydenham as one of the master-builders of the commonwealth of learning:

The Commonwealth of Learning, is not at this time without Master-Builders, whose mighty Designs, in advancing the Sciences, will leave lasting Monuments to the Admiration of Posterity; But every one must not hope to be a Boyle, or a Sydenham; and in an Age that produces such Masters, as the Great - Huygenius, and the incomparable Mr. Newton... 'tis Ambition enough to be employed as an Under-Labourer in clearing Ground a little. ${ }^{79}$

Sydenham stands in the company of Boyle, Christiaan Huygens and Newton. The most natural way to interpret Locke's comment that he himself is a mere under-labourer to the great master-builders, is that Locke sees himself as 'clearing Ground a little' for those who have contributed in a major way to Experimental Philosophy. ${ }^{80}$ If this is

\footnotetext{
${ }^{76}$ See de Beer's note to Dr Mattheus Sladus to J. G. Graevius, 22 November/2 December 1684, in de Beer (ed.), op. cit. (note 27), Vol. 2, 655.

${ }^{77}$ Peter Anstey, 'Experimental Versus Speculative Natural Philosophy', in Peter R. Anstey and John A. Schuster (eds), The Science of Nature in the Seventeenth Century: Patterns of Change in Early Modern Natural Philosophy (Dordrecht: Springer, 2005), 215-42.
}

\footnotetext{
${ }^{78}$ John Dunton, The Young-Students-Library (London, 1692), vi-vii.

${ }^{79}$ John Locke, An Essay concerning Human Understanding, P.H. Nidditch (ed.), (Oxford: Clarendon Press, 1975), 9-10.

${ }^{80}$ Ibid., 10. See Chapter 1 of Peter R. Anstey, John Locke and Natural Philosophy (Oxford: Oxford University Press, 2011).
} 


\section{The Creation of the English Hippocrates}

correct, Locke regarded Sydenham as a major contributor to Experimental Philosophy. How is this so? Locke's scattered comments about Sydenham after the publication of the Essay provide the answer.

Both Locke and Goodall remained curious to find out just how Sydenham was regarded abroad, and within months of the appearance of the Essay, in March 1690, Locke sent Dr Pieter Guenellon copies of two recent English works that (in Guenellon's words) 'tried to follow the plan of Dr Sydenham'. ${ }^{81}$ They were Morton's Phthisiologia and Walter Harris' De morbis acutis infantum, which, as we have seen, were also mentioned by Brown in his Vindicatory Schedule. We should note too that Goodall was soon to recommend Morton's book to Locke, one suspects because of the book's praise of Sydenham. $^{82}$

Meanwhile, Locke was corresponding with another promoter of Sydenham, Dr William Cole. In the early 1680s, Cole had written to Sydenham concerning hysteria, and Sydenham's reply was published as Dissertatio epistolaris ad spectatissimum doctissimumq[ue] virum Gulielmum Cole, MD (1682). Soon after Sydenham's death Cole wrote to Locke thanking him for advice on his plan to move to London to set up a medical practice. He regarded himself as likely to be scarcely visible among 'so many very great men of the Faculty' but for 'a reflex ray' from someone of the stature of Locke. ${ }^{83}$ Their mutual connection with Sydenham was the pretext for Cole to see Locke as obliging him with friendship 'in the roome of our worthy deceased friend'. ${ }^{84}$

Interestingly, it appears that Locke wrote to him on the role of hypotheses in medicine, and this too within months of the publication of the Essay, though, frustratingly, the letter no longer survives. Cole replied that 'I thinke no Hypothesis allowable which goes not upon such [mechanicall] grounds as the subject is ... so all ought, as much as is possible, to be eyther built on Experiment, or be tryed by it'. He goes on to trot out the standard line of the experimental physician and to express his confidence that Locke held the same view as Sydenham on the need to build one's method of treatment on 'a good foundation' of experiment. ${ }^{85}$

Again in 1690, Locke and Goodall distributed a questionnaire to a number of foreign physicians with a view, not only to solicit evidence about epidemic constitutions, but also to gauge the extent of Sydenham's reputation. The fourth of five questions asks after ' $[\mathrm{t}]$ he Esteeme which Physitians have had of Doctor Sydenham and his works'. ${ }^{86}$

One of the recipients was Guenellon, who was not as impressed by the English physician as perhaps Locke had hoped. In answer to query four he informed him in August 1692 that:

For with regard to the works of Mr Sydenham, we hold them in high esteem and it is certain that his plan and method are admirable, however, he is not always successful and that which he says of gonorrhea is very weak, and one will surely very often be misled following his method. ${ }^{87}$

\footnotetext{
${ }^{81}$ This is Guenellon's expression. See Guenellon to Locke, 11/21 March 1690, in de Beer (ed.), op. cit. (note 27), Vol. 4, 26.

${ }^{82}$ Goodall to Locke, 21 May 1690, ibid., Vol. 4, 83. Locke had a copy of Phthisiologia, see Harrison and Laslett (eds), op. cit. (note 19), No. 2056.
}

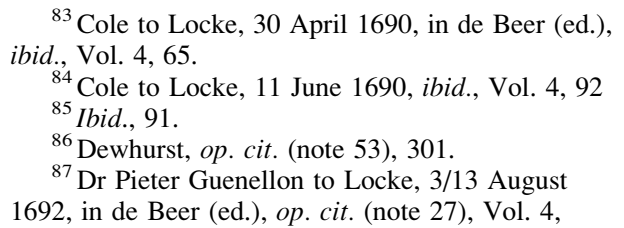




\section{Peter Anstey}

At least Guenellon's comment that Sydenham's 'plan and method are admirable' would have been pleasing to Locke, and within a few months we find Locke writing to Thomas Molyneux of that method:

That which I always thought of Dr. Sydenham living, I find the world allows him now he is dead, and that he deserved all that you say of him. I hope the age has many who will follow his example, and by the way of accurate practical observation, as he has so happily begun, enlarge the history of diseases, and improve the art of physick, and not by speculative hypotheses fill the world with useless, tho' pleasing visions. ${ }^{88}$

Note here the reference to Sydenham's writing of natural histories of disease and his denial of speculative hypotheses. These are the two hallmarks of an experimental as opposed to a speculative philosopher in late seventeenth-century England, where Experimental Philosophy was still practised according to the Baconian method of natural history. ${ }^{89}$

Let us now turn to Locke's telling reply to Molyneux's next letter:

But I perfectly agree with you concerning general theories, that they are for the most part but a sort of waking dreams, with which when men have warm'd their own heads, they pass into unquestionable truths, and then the ignorant world must be set right by them. Tho' this be, as you rightly observe, beginning at the wrong end, when men lay the foundation in their own phansies, and then endeavour to sute the phænomena of diseases, and the cure of them, to those phansies. I wonder that, after the pattern Dr. Sydenham has set them of a better way, men should return again to that romance way of physick. But I see it is easier and more natural for men to build castles in the air of their own, than to survey well those that are to be found standing. Nicely to observe the history of diseases in all their changes and circumstances, is a work of time, accurateness, attention, and judgment; and wherein if men, thro' prepossession or oscitancy mistake, they may be convinced of their error by unerring nature and matter of fact, which leaves less room for the subtlety and dispute of words, which serves very much instead of knowledge in the learned world, where methinks wit and invention has much the preference to truth. ${ }^{90}$

This letter is replete with the methodological rhetoric of Experimental Philosophy. Even the comment at the end of the letter about Sydenham's therapeutical methods serves to make a methodological point about turning 'men from visions and wrangling to observation'. ${ }^{91}$ It is Sydenham's method that Locke singles out and praises: clearly he regards Sydenham as epitomising Experimental Philosophy in medicine: he was opposed to speculation and practised Baconian natural history.

492-3. See also Pieter Guenellon to Locke 13/23 February 1693, idem, Vol. 4, 643 and 30 October/10 November 1702, idem, Vol. 7, 699; Dr Egbertus Veen to Locke, 1 February 1692, idem, Vol. 4, 372. For Dr Charles Willoughby's reply to the questionnaire from Ireland see 'On a MS of Dr Willoughby's, Written in 1690, "On the Climate and Diseases of Ireland", Proceedings of the Royal Irish Academy, 6 (1857), 399-415; reprinted in Kenneth Dewhurst, 'The Genesis of State Medicine in Ireland', Irish Journal of Medical Sciences, 363 (1956), 365-84: 370-81.

\footnotetext{
${ }^{88}$ Locke to Thomas Molyneux, 1 November 1692 , de Beer (ed.), ibid., Vol. 4, 563, underlining added.

${ }^{89}$ For the Baconian method of natural history see Peter Anstey, 'Locke, Bacon and Natural History', Early Science and Medicine, 7 (2002), 65-92; and Peter Anstey and Michael Hunter, 'Robert Boyle's "Designe about Natural History", Early Science and Medicine, 13 (2008), 83-126.

${ }^{90}$ Locke to Thomas Molyneux, 20 January 1693, in de Beer (ed.), op. cit. (note 27), Vol. 4, 628-9, underlining added.

${ }^{91}$ Ibid., 630.
} 


\section{The Creation of the English Hippocrates}

After this correspondence with Thomas Molyneux, Locke seems to have followed up another lead on Sydenham's reputation, for in early 1695 he wrote to his Scottish friend Dr John Hutton, now the Physician-General, inquiring as to the status of Andrew Brown as a physician, an inquiry that was almost certainly prompted by hearing of the Edinburgh physician's own promotion of Sydenham's method. Hutton sent Locke a thorough report on Brown, assuring him that 'He commends dr Sydenhams method in the cure off fevers beyond any other' and promising to send him Brown's Vindicatory Schedule 'if ever it come to my hand'. ${ }^{92}$ Interestingly, a letter from Brown to Hutton, including arrangements for a copy of the book to be sent to Hutton, is among Locke's papers, along with an unsigned report on Brown's status as a physician. ${ }^{93}$ Perhaps Hutton kept his promise, and the copy of the Vindicatory Schedule in Locke's library derived from Brown himself?

\section{Sydenham's Reputation on the Continent}

If Locke was concerned for Sydenham's reputation in Scotland, Ireland, France and The Netherlands, there was no need for him to worry about the reception of his friend's method in Italy. The Italian Giorgio Baglivi's De praxi medica (1696) is perhaps the most effusive continental work to discuss Sydenham's medical methodology in the late seventeenth century. After an extended list of speculative physicians and their hypotheses, Baglivi tells us that:

[T] he World would have groan'd under the spreading of that dismal Fire [of fevers untreated due to speculative hypotheses], if one Author, among so many, had not shone out in this Age, I mean Thomas Sydenham, the Imbellisher and Ornament of our Profession, who laying aside the Fictions of Opinion, applied himself wholly to Observation, and ... at last disclos'd a more probable Hypothesis of the Nature of Fevers, and a more plausible Method of Cure'. ${ }^{94}$

Then in Chapter Six, Baglivi goes on to illustrate the history of diseases, following the method of Sydenham, and gives a description of gout. Later he calls Sydenham 'the most diligent Observator we have had since Hippocrates' ${ }^{95}$

The popularity of Sydenham amongst Italian physicians in the late seventeenth century is not hard to explain. From at least the 1660s, Italian natural philosophers had embraced Experimental Philosophy and decried speculation. The preface to the Saggi di naturali esperienze (1667) of the Accademia del Cimento expressed the ambition of the Italian academy in terms that must have resonated with the English experimental philosophers, casting their work as a contribution to the vast project of natural history and expressing an aversion to speculation,

\footnotetext{
${ }^{92}$ Dr John Hutton to Locke, 27 April 1695, ibid., Vol. 5, 354, 355.

${ }_{93}$ The letter and report are transcribed in ibid., Vol 5, 382-3.

${ }^{94}$ Quoting the English translation of Giorgio Baglivi, De praxi medica (Rome, 1696), The Practice of Physick, Reduc'd to the Ancient Way of
}

Observations (London, 1704), 143. See also Conrad Sprengell's, Natura morborum medicatrix (London, 1705), 317 for an implicit aligning of Hippocrates with both Sydenham and Baglivi. Sprengell's work was printed with Matthias Purmann's Chirurgia curiosa (London, 1706).

${ }^{95}$ Baglivi, ibid., 318. 


\section{Peter Anstey}

We are unwilling any should imagine, That we pretend in this Publication, a Perfect Work; or in the least, an Exact Module of a large Experimental History; conscious to our selves, that more Time, and greater Abilities are necessary to so vast a Design ... if sometimes, as a Transition from one Experiment to another, or upon what occasion soever, there shall be inserted any hints of Speculation, we Request they may be taken always for the thoughts, and particular sense of some one of the Members, but not imputed to the whole Academy, whose sole Design is to make Experiments and Relate them. ${ }^{96}$

There was even a debate about the limited utility of anatomy for physic in Italy that had close parallels with the debate in England. ${ }^{97}$

When we turn to Baglivi's correspondence, the very same themes are apparent. He wrote to the Swiss physician Jean Jacques Manget on 1 August 1693 expressing his desire for works of practice that avoid hypothetical fictions (hypothesum figmentis) rather than works of theory in medicine and praising 'that immortal Sydenham' for showing what can be done in this regard. ${ }^{98}$ Manget replied that he himself tries to avoid hypotheses in his descriptions of disease, though he was less sanguine about Sydenham's success in avoiding them. ${ }^{99}$

Now it might be thought that Baglivi's championing of Sydenham as the opponent of hypotheses and promoter of observation is entirely independent of Locke's own promotion of Sydenham's reputation, and to a certain extent this is true. However, the indirect influence of Locke cannot be entirely ignored, for, while Sydenham's works are occasionally punctuated with methodological outbursts about his avoidance of speculation and hypotheses and his writing of natural histories, ${ }^{100}$ the only sustained methodological writing in any of his works is the preface to the Observationes medicae (1676), which was almost certainly written in collaboration with Locke and bears the marks of Locke's influence throughout. The overt methodological orientation which Baglivi discovered in Sydenham's writings and sought to emulate was, in part, shaped by Locke.

\section{Sydenham in the Early Eighteenth Century}

Locke's writings were enormously popular and influential. His Essay was translated into both French and Latin in 1700 and, within four years of his death in 1704, a number of important posthumous writings had appeared. In 1706, Jean Le Clerc published his The Life and Character of Mr John Locke which contained a quote of both the Latin and English acknowledgment of Locke from Sydenham's dedicatory epistle to the Observationes

\footnotetext{
${ }^{96}$ Quoting Richard Waller's translation, Essayes of Natural Experiments Made in the Academie del Cimento (London, 1684), Sig. b2v-b3r.

${ }^{97}$ See Howard B. Adelmann (ed.), Marcello Malpighi and the Evolution of Embryology, 5 vols (Ithaca, NY: Cornell University Press, 1966), Vol. 1, 558-87.

${ }^{98}$ Baglivi to Manget, 1 August 1693, in Dorothy M. Schullian (ed.), The Baglivi Correspondence from the Library of Sir William Osler (Ithaca, NY: Cornell
}

University Press, 1974), 112 and note 26 on 114, for further references to Sydenham in Baglivi's Opera omnia (Lugduni, 1704).

${ }^{99}$ Manget to Baglivi, 17/27 September 1693, in Schullian, ibid., 117-18.

${ }^{100}$ See, for example, Sydenham's claim that he does 'not venture to speculate beyond what I am taught by the facts themselves' immediately after his reflections on the miasmic origin of smallpox, Works of Thomas Sydenham, op. cit. (note 30) Vol. 1, 220. 


\section{The Creation of the English Hippocrates}

medicae. ${ }^{101}$ Then in 1708, Some Familiar Letters appeared containing the letter to Thomas Molyneux praising Sydenham's method. ${ }^{102}$

Given the connection between Locke and Sydenham, and Sydenham's popularity in Italy, it is hardly surprising that others would pick up the image of the English Hippocrates. Herman Boerhaave famously praised Sydenham for being Hippocratic in his method in his public oration in 1701, when taking up a lectureship in medicine at Leiden:

[A]mong the later writers on practical medicine few or none have achieved the perfection of the Ancients.... Among them I consider Thomas Sydenham to be a unique and exceptional figure the Light of England, a Phoebus in our Art. I would be ashamed to mention his name without a reverential epithet; whenever we contemplate him, the true image of the Hippocratic man is evoked in our mind, and however magnificently I may extol his merits for the Commonwealth of physicians, his worth will outdistance this praise. ${ }^{103}$

Slightly more revealing are the references to Sydenham in obiter dicta from the period. These passing comments shed light on the popular image of the long-deceased physician. Two good examples are found in the correspondence of James Jurin. Perrott Williams wrote to Jurin, then Secretary of the Royal Society, on 11 January 1724:

I can't forget an Observation, made on the like occasion by the Sagacious and honest Dr Sydenham - viz. 'There are two sorts of men who more especially are lets and hindrances to medical progress. First come those who, adding nothing to medicine of their own, are angry at the most trifling additions of another.... Another sort affects the title of uncommon wisdom, by overloading practice with impractical speculations... ${ }^{104}$

Note the reference to 'impractical speculations' here. In another letter to Jurin from Edward Bayly in the following month, we find that with regard to collecting information on weather and the incidence of disease:

[T]hose Physicians Surgeons and Apothecarys who shall think fit to joyn in this Undertaking and thus we may be furnished with the History of Diseases too, which must be of great Use in Practice as well as Theory, and is what seems to have been pretty much the Study of some of [the] Greatest Masters as Hippocrates, Sydenham \&c But has been too much neglected by the most part. ${ }^{105}$

However, again there is no comment on the content of Sydenham's actual contribution to medicine, no reference to his medical receipts or even to specific natural histories of

\footnotetext{
${ }^{101}$ Jean Le Clerc, The Life and Character of Mr John Locke (London, 1706), 3-4.

${ }^{102}$ John Locke, Some Familiar Letters between Mr Locke and Several of his Friends (London, 1708), 283-6.

${ }^{103}$ E. Kegel-Brinkgreve and A.M. LuyendijkElshout (eds), Boerhaave's Orations (Leiden: Brill, 1983), 78. See also Boerhaave's A Method of Studying Physick (London, 1719), 316: 'Sydenham, whom no one ought to mention but with Honour. This Author laying aside all Pomp of Learning and Systems, did nothing else but observe by the Clinica Methodus of the Ancients what happen'd in Distempers'. Andrew Cunningham claims that it was
}

Boerhaave "who made Sydenham into one of the great masters of the history of medicine', in Andrew Cunningham, 'Thomas Sydenham: Epidemics, Experiment and the "Good Old Cause", in Roger French and Andrew Wear (eds), The Medical Revolution of the Seventeenth Century (Cambridge: Cambridge University Press, 1989), 164-90: 189, but he entirely ignores the roles of Locke and Baglivi.

${ }^{104}$ Perrott Williams to James Jurin, 11 January 1724, Andrea Rusnock (ed.), The Correspondence of James Jurin (1684-1750) (Amsterdam: Rodopi, 1996), 222, underlining added.

${ }^{105}$ Edward Bayly to James Jurin, 29 February 1724, ibid., 234, underlining added. 


\section{Peter Anstey}

disease. Instead the reputation is spelled out in terms of his avoidance of speculation and his commitment to natural history.

This is not to say that no one was critical of Sydenham's methodology. As early as 1703 we find Peter Paxton claiming that since the time of Hippocrates, physic had been grounded upon speculative theories, but that 'some steps' had been 'made towards a Reformation ... several Eminent Men having attempted to reclaim Mankind from some of these prejudices; and amongst such, as justly deserving to be first named, the judicious D. Sydenham'. However, Paxton goes on to criticise him:

$[\mathrm{N}]$ otwithstanding that excellent Person, exploded Hypotheses and Speculations, as unfit and unsafe to be intermixed with Practice, yet so far was he prejudiced with the receiv'd Notions of distinct kinds of Diseases, and their common Natures, that he only pursues the Writing of the general Histories of Diseases; and then He, admitting of Alterations from the first Qualities that did not relate to the Essence of the Diseases, hath from these Reasons somewhat sullied the Advantages that otherwise might have been gather'd from his practical Method. ${ }^{106}$

Another critic was James Keill who, in his An Account of Animal Secretion, the Quality of Blood in the Humane Body, and Muscular Motion (1708), praises Sydenham's histories of diseases, but criticises him for decrying natural philosophy, that is theory. ${ }^{107}$ Yet even these critics are testimony to the fact that it was the decrying of speculation and the commitment to natural history that were the hallmarks of the eighteenth-century image of Sydenham the experimental physician.

\section{Conclusion}

By the early 1700s, the image of Thomas Sydenham as the English Hippocrates, the decrier of speculation and hypotheses and the practitioner of natural history, was established. An excerpt from an ode by the author and physician George Sewell to Sir Richard Blackmore, sometime poet and physician, captures the tone perfectly,

Too long have we deplor'd the Physick State,...

Then vain HYPOTHESIS, the Charm of Youth, Oppose'd her Idol Altars to the Truth; ...

SYDENHAM, at length, a mighty Genius, came, Who founded Medicine on a nobler Frame, Who studied Nature thro', and Nature's Laws, Nor blindly puzzled for the peccant Cause. Father of Physick He - Immortal Name!

Who leaves the Grecian [Hippocrates] but a second Fame:

${ }^{106} \mathrm{P}$ [eter] P[axton], The Grounds of Physick Examined (London, 1703), 49-50, underlining added.
${ }^{107}$ James Keill, An Account of Animal Secretion, the Quantity of Blood in the Humane Body, and Muscular Motion (London, 1708), xxiii-xxiv. 


\section{The Creation of the English Hippocrates}

Sing forth, ye Muses, in sublimer Strains

A new HIPPOCRATES in Britain reigns. ${ }^{108}$

His fame then rested on his supposed medical methodology, as it does today. He made no new medical discoveries, he developed no effective cures for diseases, many of his descriptions of particular diseases are now considered to be inadequate and often indeterminate. $^{109}$

It is, therefore, highly ironic that even a cursory perusal of his writings reveals that Sydenham did indulge in speculation. He had a highly speculative theory of fevers and was committed to a vis medicatrix naturae which, in spite of his disavowal of such a notion, was a kind of world soul responsible for the course of diseases and the curative processes in bodies. ${ }^{110}$ Furthermore, his treatments were usually predicated upon speculative theory: he used children to warm sick bodies because 'a notable supply of fresh effluvia from a sound and athletic body may be transfused into a sick and exhausted one'. ${ }^{111}$ His theory of the cause of gout was criticised as a fiction by Martin Lister. ${ }^{112}$ His treatment of cooling regimens for smallpox was extremely controversial and often harshly criticised. ${ }^{113}$ Even his so-called natural histories of disease were hardly different from the descriptions of diseases of other writers on fevers. They were, by Sydenham's own admission, not case histories, but descriptions of the phenomena of particular diseases and 'established practises \& methods of cureing, collected from a carefull observation of a great number of instances'. ${ }^{114}$ Nor was he the first to promote them or construct them. ${ }^{115}$ Yet through the efforts of a small number of enthusiastic supporters, Sydenham, opponent of the book learning and medical method that typified the Fellows of the

${ }^{108}$ Richard Blackmore, A Treatise of Consumptions and Other Distempers Belonging to the Breast and Lungs, 2nd edn (London, 1725), Sig. b1-2.

${ }^{109}$ See Rather, op. cit. (note 9), 7-8.

${ }^{110}$ For Sydenham's claim that 'nature' refers to 'the whole complex of natural causes' as regulated by God see Methodus, op. cit. (note 13), 215;

Observationes medicae, II. ii. 48, Works of Thomas Sydenham, op. cit. (note 30) Vol. 1, 119-20. For further discussion see Rather, ibid., 88-94.

${ }^{111}$ Sydenham, Methodus, op. cit. (note 13), 53.

${ }^{112}$ Martin Lister, Octo exercitationes medicinales (London, 1697), 188.

${ }^{113}$ See, for example, Gideon Harvey, A New Discourse of the Smallpox and Malignant Fevers (London, 1685), 194.

${ }^{114}$ Sydenham in Meynell (ed.), op. cit. (note 20), 11. There has been a recurrent misunderstanding since Sydenham's day that his natural histories are case histories. For a contemporary example see the 'Sydenhamian' histories of Richard Morton's Phthisiologia, which Guenellon took to be following Sydenham's method, see op. cit. (note 81). For a more recent example of this misunderstanding see James C. Riley, The Eighteenth-Century Campaign to Avoid Disease (London: Macmillan, 1987), 1. G.G. Meynell has pointed out that Sydenham 'never, except for smallpox and measles, provided a description of the course, day by day, of either an individual or an idealised case', notes to op. cit. (note 20), 186. Case studies do appear in Sydenham's writings but they are uncommon.

${ }^{115}$ From the early 1660 s, the history of diseases had formed part of the Baconian programme for natural history. Robert Boyle and Christopher Wren, among others, openly called for such histories and a number of virtuoso-physicians, such as Timothy Clarke and Daniel Coxe, adopted the method of natural history. For Wren's call for histories of diseases see Christopher Wren, Parentalia (London, 1750), 223. For Boyle, see his, 'General Heads for a Natural History of a Countrey [sic]', Philosophical Transactions, 1 (1666), 186-9: 187 and especially his 'Topics for the History of Diseases', in Michael Hunter (ed.), Robert Boyle's 'Heads' and 'Inquiries', Robert Boyle Project Occasional Paper No. 1 (London: Robert Boyle Project, Birkbeck College, 2005) 33-4 (a copy of these heads is in Locke's notebook, Bodleian Library MS Locke c. 42 (part 1), 98 ). For references to histories of disease in Boyle's Usefulness of Natural Philosophy, II, $i,(1663)$ see, for example, Hunter and Davis (eds), op. cit. (note 41), Vol. 3, 322, 534. 
College of Physicians, emerged from the seventeenth century as a hero in medicine. ${ }^{116}$ The bust of Sydenham in the Wren Library is an iconic manifestation of this, the creation of the English Hippocrates.

\section{Acknowledgements}

I am grateful to Michael Hunter, Antonio Clericuzio, Juan Manuel Gomez and the anonymous referees for Medical History for their comments on a draft of this article.

${ }^{116}$ It is a moot point as to just what Locke himself would have thought of the epithet 'the English

Hippocrates'. Locke, as is well known, referred to his friend as Aesclepius, an allusion to the Greek god of medicine and healing. Sydenham himself was the first to draw a connection between his medical method and that of Hippocrates. There are four references to Hippocrates in the preface to his Observationes medicae (Works of Thomas Sydenham, op. cit. (note 30) Vol. 1, 11, 16, 18 and 24). 